\title{
Compliance, concordance, and patient-centered care
}

\author{
This article was published in the following Dove Press journal: \\ Patient Preference and Adherence \\ 8 February 201I \\ Number of times this article has been viewed
}

\section{Sharon Lawn \\ Flinders Human Behaviour and Health Research Unit, Margaret Tobin Centre, Flinders University, Adelaide, South Australia}

Correspondence: Sharon Lawn Flinders Human Behaviour and Health Research Unit, Margaret Tobin Centre, Flinders University, GPO Box 2100 , Adelaide 500I, South Australia

Tel +6I 88404232 I

Fax +6I 884042101

Email sharon.lawn@health.sa.gov.au
Since the appearance of the WHO compliance-adherence report ${ }^{1,2}$ we have had confirmed what many patients and health professionals have known for a long time, that many patients simply do not follow health professionals' advice - they vary that advice to suit their needs. Also, health professionals often do not follow evidence-based guidelines when providing treatment and care to patients. We have tended to cope with these phenomena by labeling patients as 'noncompliant', or, worse, and have denied them treatment access in some settings or imposed treatment against their will. Mental health settings provide a stark focused lens on this phenomenon, but it likely pervades many other areas of health care.

In a recent attempt to unpack the discourse around concordance, compliance, preference, and adherence, Fraser ${ }^{3}$ argued for the term 'concordance', by which the health professional and patient strive for a more equal relationship in deciding goals for treatment and enforced treatment is avoided. He concluded that, 'the bottom line is that it doesn't matter what you call it as long as the patient takes the correct medication at the correct time and at the correct dose' (p. 96). Holding that this is true, he attaches the rider that cognitive and social problems within the patient affect their capacity to achieve this. Yet, I believe that this approach continues to miss some very important and fundamental value shifts that need to occur, if truly patient-centered care is to be achieved by health professionals. It also places the lived experience and social determinants surrounding the patient as second to health professional expertise based purely on 'the science'. It runs the risk of continuing to be understood as compliance to what the health professional says should happen, rather than genuine concordant processes that fully acknowledge the patient's role in decision-making about treatments.

We would like to believe that health professional expertise and decisions are always based on rigorous science. We have certainly come a long way in the past 100 years of research and practice and we know much more about causes of disease and their effective treatment. But we still have much to understand about the cycle and path of illness, particularly the unique ways by which it displays itself in each individual and how they respond and make sense of the experience as part of what we all do to strive to make sense of our world. Cancer care is one such area where, arguably, many unknown variables are at play. Psychotic illness such as paranoid schizophrenia is another example where the person is 'working hard' to make sense of what is occurring, not passively experiencing it, albeit doing so with a range of cognitive processes that may lead them to false conclusions about that experience. 
So, concluding statements like Fraser's seem to fall short somehow. All will not necessarily be well by taking the correct medication at the correct time and at the correct dose. Illness and lived responses to it involve and require more than this. I believe that a more preferable bottom line is that whatever treatment is given to the patient by the health professional, it should suit the patient's needs and actually ameliorate or cure the health condition for which the patient has come to seek help, while minimizing other unwanted effects, as experienced and tolerated by the patient. They must live with their health conditions, after all.

\section{Disclosure}

The author declares no conflicts of interest, and received no funding to write this manuscript.

\section{References}

1. World Health Organization. Adherence to long-term therapies: evidence for action. Geneva, Switzerland: World Health Organization; 2003.

2. Vermeire E, Hearnshaw H, van Royen P, et al. Patient adherence to treatment: three decades of research: a comprehensive review. $J$ Clin Pharm Ther. 2001;26(5):331-342.

3. Fraser S. Concordance, compliance, preference or adherence. Patient Prefer Adherence. 2020;4:95-96.

\section{Publish your work in this journal}

Patient Preference and Adherence is an international, peer-reviewed, open access journal focusing on the growing importance of patient preference and adherence throughout the therapeutic continuum. Patient satisfaction, acceptability, quality of life, compliance, persistence and their role in developing new therapeutic modalities and compounds to optimize clinical outcomes for existing disease states are major areas of interest. This journal has been accepted for indexing on PubMed Central. The manuscript management system is completely online and includes a very quick and fair peer-review system. Visit http://www.dovepress.com/ testimonials.php to read real quotes from published authors. 